\title{
Controversies in cardiothoracic surgery: Should therapeutic cloning be supported to provide stem cells for cardiothoracic surgery research and treatment?
}

Martin McKneally, MD

From the Department of Surgery and Joint Centre for Bioethics, University of Toronto, Toronto, Ontario, Canada.

Received for publication Nov 28, 2005; accepted for publication Dec 12, 2005.

Address for reprints: Dr. Martin F. McKneally, 77 Forest Grove Drive, Toronto, ON M2K 1Z4, Canada (E-mail: martin. mcneally@utoronto.ca).

J Thorac Cardiovasc Surg 2006;131:937-40 0022-5223/\$32.00

Copyright (C) 2006 by The American Association for Thoracic Surgery

doi:10.1016/j.jtcvs.2005.12.049
7 he excitement and controversy surrounding the use of embryonic stem cells were captured by 2 outstanding scholars who presented their arguments in a brilliant debate, genially and thoughtfully moderated by Bob Guyton of Atlanta, Chief of Cardiothoracic Surgery at Emory University. Their arguments are summarized here using the words of the debaters as much as possible. Both have reviewed and approved this condensed version.

Pro: Paul Berg, Cahill Professor of Cancer Research at Stanford, won the Nobel Prize in Chemistry in 1980 for developing methods that make it possible to analyze the structure and function of DNA and its role in the development of genetic engineering. Professor Berg opened the debate by expressing his hope, as a patient who has survived a heart attack, that stem cells could one day be used to repair the injured myocardium. He then described the origin and capabilities of stem cells. There is 1 tissue-specific stem cell in every 25,000 bone marrow cells, and one of these stem cells can rescue a mouse after lethal marrow ablation. They cannot differentiate into other somatic cells such as cardiac, neural, or pancreatic cells. In contrast, embryonic stem cells are derived from a blastocyst, a relatively undifferentiated structure of 100 to 150 cells that develops 4 to 6 days after fertilization of an oocyte-an egg cell. About 30 cells, comprising the inner cell mass of the blastocyst, are pluripotent embryonic stem (ES) cells; they give rise to all of the cell types of the adult organism. ES cells can be propagated in tissue culture, and they retain their pluripotentiality during long periods of frozen storage. These attributes have made them an attractive starting point for therapies aimed at tissue regeneration. Furthermore, ES cells can be induced to differentiate by manipulation of the medium into neurons that can be implanted into the brain to make functional electrical connections and produce dopamine, beta islet cells of the pancreas that produce insulin, and cardiomyocyte clusters that can beat in rhythm.

Human trials, done mostly in Europe, mostly without any controls, have explored the effect of infusing or injecting bone marrow-derived stem cells into the myocardium of a few hundred heart attack survivors with heart failure. There have been claims of varying degrees of clinical improvement in cardiac function, but without controls this conclusion is dubious. What little clinical improvement has been seen, however, could not be ascribed to engraftment of the injected cells. It is likely that growth factors present in the bone marrow suspension secreted by the injected cells are what would account for any apparent repair. ${ }^{1}$

By contrast there is clear and convincing evidence that injection of bone marrow-derived cells does not give rise to myocytes. After injection of genetically tagged, fluorescent hematopoietic stem cells into an infarcted site, the only fluorescent cells in the myocardium were those that had adopted the classic hematopoietic 
fates, and not those of myocytes. ${ }^{2}$ Many such negative experiments support the view that hematopoietic stem cells do not transdifferentiate into myocytes.

With respect to the potential of using ES cells to repair damaged hearts, a recent minireview in Cell states: "Embryonic stem cells possess the capacity to differentiate into cardiac myocytes that resemble fetal or embryonic cardiac myocytes. Such cardiac myocytes flux calcium, have spontaneous action potentials, spontaneously contract, and they will engraft and electrically and mechanically couple to host cardiac myocytes when transplanted into the heart." ${ }^{3}$ Despite such desirable properties, attempts to use ES cells clinically have been avoided because of the ethical storm that has been raised about the derivation of ES cells and the fear that the injection of ES cells into the heart might produce teratomas and cardiac arrhythmias. Nevertheless, 1 such attempt by Weissman and Robins at Stanford has shown considerable promise. They injected allogeneic fluorescently labeled mouse ES cells into mice whose hearts' left anterior descending artery had been ligated. Examination of the infarcted site at varying periods revealed that about $50 \%$ of the infarcted area was populated by a dense collection of fluorescent cardiomyocytes expressing a characteristic protein pattern. Coinjection of the ES cells with growth factors gave an enhanced effect, particularly in the hearts' functional capacities.

By far the greatest impediment to the use of stem cells is the histoincompatibility between the source of the cells and the recipient. This is true for the use of adult-derived cells from an unmatched donor and cardiomyocytes derived from ES cells that can be obtained from the leftover embryos of in vitro fertilization (IVF) clinics. It is for that reason that we need to produce what Professor Berg refers to as "patient-specific" stem cells. The procedure for producing such patient-specific stem cells is still being worked out. Progress along these lines has been slowed by ethical arguments but more seriously is in danger of being made a criminal offense. The derivation of patient-specific stem cells is the process that has been erroneously referred to as "therapeutic cloning." Professor Berg prefers to refer to it as the "production of patient-specific stem cells" because that is the intent. The process is quite straightforward and can be made quite efficient in production of specific stem cell lines that are matched to any 1 individual. The process involves taking an unfertilized egg, harvested from a woman by normal procedures in an IVF clinic, and removing the nucleus. The nucleus is replaced by another derived from any cell from the patient to be treated. With some frequency, this reconstituted, nucleated egg undergoes cell division, forms the blastocyst and produces a batch of ES cells. Those ES cells have the same genetic makeup as the individual who contributed the nucleus and it is these socalled patient-derived stem cells that we can foresee as being the root for therapies to avoid the histoincompatibility problem that would occur if one transferred cells that are now available in culture or from transfer of adult stem cells unless those cells are derived from the patients themselves. So far that seems unlikely.

Con: Eric Cohen is Director of the Biotechnology and American Democracy program at the Ethics and Public Policy Center in Washington, DC, editor of The New Atlantis (a journal about the ethical, political, and social implications of technological advancement), and Consultant to the President's Council on Bioethics. Cohen framed the question before us as whether this particular means of advancement, the creation and destruction of human embryos, is an ethically responsible approach. The embryo research debate has raised fundamental questions about the aspirations of medicine, the meaning of equality, the origin of human life, and the spirit of human progress.

The embryo, the smallest human organism, sets before us the biggest questions. Whether we should create and destroy cloned human embryos for research is a moral question that scientists cannot answer with scientific principles. Citizens must answer, based on ethical principles and ethical reasoning. A responsible public debate requires 3 things: honest science, honest language, and careful ethical reasoning.

Honest science is unclouded by excesses of enthusiasm. Hype and hope ran ahead of reality in the gene therapy and fetal tissue debates and may be doing so in the embryonic stem cell debate. The fairy tale that stem cells are the most promising approach to curing Alzheimer's disease has been repeated over and over, most prominently in the recent election campaign in California.

Second, we need honest language. "Nuclear transfer to produce stem cells" is an accurate technical account, but it misses the fundamental ethical question. To engage in nuclear transfer, you have to produce and destroy a cloned human embryo, and that is the heart of the public debate.

Third, we need careful ethical reasoning. It is ironic that those who see embryos as insignificant (no bigger than the period at the end of this sentence when stem cells are harvested) also desperately want them; it is not an ethical argument for why human embryos should be available for our use and destruction. Pursuit of a cure is an ethical goal but is not by itself a moral argument for why this particular means is ethically justified. The very powers of differentiation that embryos possess when turned into embryonic stem cells might be inseparable from the kind of beings that they are.

All of us hold dear the principle of human equality - that all human individuals, old and young, weak and strong, vulnerable and healthy, possess a dignity that makes them inviolable. This principle places a claim on us as members of society that we should not discriminate against people based on certain missing attributes. If we trace back our own 
development from adulthood to infancy to the embryonic stage, we have to ask ourselves "at what point did I come into existence?" After conception, there are significant moments-when an embryo takes a discernable form, or when developing life can first begin to feel suffering. These are not changes that mark the emergence of a new human person but the arrival of certain attributes in an existing person. To treat the weakest human beings as things available for our use would violate the principle of human equality upon which a decent democratic society rests.

Eric Cohen wondered whether it is good medicine to advise women to be a source of oocytes, engaging in a procedure that is not high risk but not without risks. What kind of a society will we be if we create a huge market for human eggs, or base the advancement of medicine on their availability? Though we'll try to set limits to prevent reproductive cloning, as many nations already have, we have to ask ourselves if it is wise to have the best scientists in the world publishing articles that make their technological knowledge available to rogue scientists who will break whatever policies we put in place.

Doctors have to be not only curers, but caregivers. This requires an understanding of what it means to age, grow frail, and get sick - to be aware of one's own coming mortality. These fundamental human sensibilities of a good doctor cannot be supplied by science. A physician's understanding of limits includes the idea that there are certain things a doctor cannot do, even if it would cure a patient. We do not harvest organs recklessly; we do not have a market in organs, even though it would increase the supply. Creating a market for human embryos may change society. We need to ask what kind of a society we would become if we began using the seeds of the next generation as tools to serve our own or if we laid the foundation of medical progress on the creation and destruction of cloned human embryos.

Rebuttals: Paul Berg described mutations that predispose to early Alzheimer's disease. Creating embryonic stem cell lines with these mutations would allow mapping the biochemical pathways and exploration of methods to treat and even prevent the disease. Although there is no evidence that stem cells have cured disease, there are proof of principle experiments in mice that they can be differentiated into dopamine-producing neurons and insulin-producing beta cells and can help repair a damaged spinal cord. He warned against proposed legislation to criminalize stem cell research-threatening US citizens with $\$ 10,000,000$ fines and 10 years in prison if they access patient-specific stem cell therapy in countries like Britain that are developing this technology. Professor Berg cited prominent prolife advocate Senator Warren Hatch, who makes a moral distinction between the blastocyst in the uterus and the blastocyst in a petri dish. Hatch feels that using stem cells for therapies that may cure tens of thousands of people is more prolife than opposing their use. Berg closed with an optimistic report from South Korea, where somatic cell nuclear transfer researchers describe efficient propagation of stable long-term stem cell lines from 1 in 3 to 4 eggs. (This report, subsequently shown to be fraudulent, has been retracted.)

Cohen granted that Alzheimer's stem cell lines would allow scientists to study the disease but then quoted the testimony of a leading expert in Alzheimer research, Dennis Selcoe of Harvard Medical School. Selcoe told the President's Council on Bioethics that stem cells are very far from being the most promising avenue for curing Alzheimer's, and presenting it as being so is an irresponsible way to engage in this public debate. Cohen emphasized that America does not have a ban on stem cell research; in fact it has the most unregulated environment in this area, arguably, of any civilized nation of the world. He clarified the prohibition against using National Institutes of Health funds for embryonic stem cell research, emphasizing that the debate is about whether citizens who believe that this research is wrong should be forced to pay for it through the public purse.

Audience discussion: Gus Mavroudis, from Chicago, cited two US legal precedents related to abortion: (1) the legal and moral standing of the fetus, and by inference that of the blastocyst, ranks below that of the mother when pregnancy endangers her life; (2) survivability outside the uterus is an accepted legal threshold for personhood. Eric Cohen responded that in embryo research, there is no direct conflict between the life of an ex vivo embryo and the life of a mother. The researcher does not triage the life of this embryo versus the life of a particular patient. In contrast, embryo research involves a speculative project without genuine evidence that it might cure hypothetical future patients. Viability is not the key issue, as even a young infant, once born, could not survive on its own if abandoned. The issue is what do we owe to a living human organism, a life in process, as those to whom its care has been entrusted. Paul Berg responded that many religions define personhood later in gestation, and the Jewish religion makes curing the ailments of living people a moral imperative. He indicated that many countries, including Britain, Singapore, South Korea, Israel, and Australia, and many US states, have passed legislation to enable embryonic stem cell research to go forward.

Claudio Guareschi, from Greenville, SC, compared the status of the neurologically undeveloped embryo as a tissue donor to the brain-dead organ donor. Eric Cohen responded with a moral distinction between donors whose cognitive function has ceased forever and embryos that are developing toward full cognitive function. He closed by acknowledging that our visceral reaction to the embryo in the petri dish, which we can barely see, is different from our emotional response to the sick person we know and love and desper- 
ately want to save. Reminding us that an emotion is not a moral argument, he recommended that we err on the side of life, and a basic commitment to human equality, by seeking other avenues to advance modern medicine.

Comment: President Tirone David and the AATS Council took a courageous step when they accepted the suggestion from the Ethics Forum that this polarizing ethical issue be debated at the 2005 Annual Meeting. An "issue" is an important social question on which reasonable and fairminded people can disagree. Issues arise in professional discourse and clinical practice. These can generally be resolved by recourse to facts. In public policy, governance, and ethics, values have a more dominant role in settling issues. In the debate about using embryonic stem cells to repair the injured heart, the facts set forth and logically argued by Professor Berg lead inexorably to the conclusion that embryonic stem cells will be able to repair the injured myocardium. Eric Cohen's value-based counterargument is equally compelling, that killing a human embryo to harvest stem cells will violate the most fundamental value of a just, democratic society and a caring profession-the preservation of even the most vulnerable of human lives. His position was based entirely on classical democratic principles rather than religious faith.

This is a classic ethical dilemma. Literally, a dilemma comprises two "lemmas"-logical arguments based on sound premises - that lead to contradictory conclusions. In this debate the conclusions are contrary rather than contradictory; they disagree but do not mutually exclude. If stem cells could be harvested and propagated without terminating the life of an embryo, resolution could be achieved, in the same way that we resolve the issue of harm to the donor for the benefit of the recipient of an organ transplant. We remove 1 kidney or 1 lobe of the lung or liver without sacrificing the life or long-term well-being of the donor. The technology is now well developed for removing a few embryonic cells at the 8- to 16-cell stage of development after in vitro fertilization for diagnosis of genetic disease and selection of healthy embryos. Implanting the embryo after this in vitro intervention results in healthy babies. ${ }^{4}$ I share Professor Berg's trust in scientific progress; I believe that harvest of stem cells will become feasible without harm to the donor embryo. This solution will not fully resolve the moral problem of creating and destroying human lives, as described by Eric Cohen, unless the unharmed embryo is not destroyed.

The alternative of redefining the boundary of human life by a socially constructed agreement (eg, 14 weeks' gestation, etc) has been used very effectively for social purposes at the other end of life- to harvest vital organs from those considered to be brain dead. The moral reasoning elaborated by Eric Cohen would allow that boundary at the end of life to be advanced because there is no prospect of recovery, but consensus on brain death is incomplete. Not all jurisdic- tions, religions, and cultures accept brain death. Pioneering cardiac surgeon Juro Wada was charged with murder in Japan for harvesting the heart of a donor who was "dead" only by Western neurological criteria. The useful social construction of a redefinition of death as brain death has allowed us to harvest vital organs from patients whose heart is beating, assuring their corporeal death. This has brought the gift of life to recipients, but those who harvest know that an uneasy, almost complicit silence usually falls over the room after removal of the heart and lungs. That silence is a requiem, rooted in a deeply ingrained cultural reverence for life, what Leon Kass, the Chairman of President George W. Bush's Council on Bioethics, has called the "life principle." I will close with his recent comments about the Council's report: 'Important though it is, the 'life principle' cannot continue to be the sole consideration in public bioethical discourse. Some efforts to prolong life may come at the price of its degradation, the unintended consequences of success at life-saving interventions. Other efforts to save lives might call for dubious or immoral means, while the battle against death itself-as if it were just one more disease - could undermine the belief that it matters less how long one lives than how well. At the beginning of life, certain modes of conceiving children-for example, by cloning - threaten human dignity, even if no embryonic lives should be lost in the process. And, in extreme circumstances, perhaps, lives may even need to be risked or even sacrificed so that the community might survive and flourish Such questions of the good life- of humanization and dehumanization - are of paramount importance to the field of bioethics and to the future of our nation and the human race." 5

I'm convinced that good faith efforts, respectful of opposing values and beliefs, will lead us to an acceptable resolution. In the interim, this outstanding debate is available to be viewed in more detail at www.aats.org/2005webcast/wednesday.html. The Webcast will help you think about this important issue using clearly articulated scientific and value-based conceptual frameworks. You will be inspired by the speakers and proud of the profession.

I am grateful to Deborah McKneally for helpful suggestions that improved earlier versions of this manuscript.

\section{References}

1. Couzin J, Vogel G. Renovating the heart. Science. 2004;304:192-4.

2. Murry CE, Soonpaa MH, Reinecke H, et al. Haematopoietic stem cells do not transdifferentiate into cardiac myocytes in myocardial infarcts. Nature. 2004;428:664-8.

3. Parmacek MS, Epstein JA. Pursuing cardiac progenitors: regeneration redux. Cell. 2005;120:295-8.

4. Nisker JA, Gore-Langton RE. Pre-implantation genetic diagnosis: a model of progress and concern. J SOGC. 1995;17:247-61.

5. Kass L. Reflections on public bioethics: a view from the trenches. Kennedy Institute of Ethics Journal. 2005;15:221-50. 